\title{
UJI PENGARUH JARAK SUMBER PANAS DAN LAMA PENGASAPAN TERHADAP KARAKTERISTIK KIMIA IKAN LELE (Clarias Sp.) ASAP PADA ALAT PENGASAP TIPE TEGAK
}

\author{
INFLUENCE OF HEAT SOURCE DISTANCE AND SMOKING TIME TO THE CHEMICAL \\ CHARACTERISTICS OF SMOKED CAT FISH (Clarias sp.) USING STANDING TYPE OF \\ SMOKED EQUIPMENT
}

\author{
Rofandi Hartanto ${ }^{1}$, Bambang Sigit Amanto ${ }^{1)}$, Lia Umi Khasanah ${ }^{1)}$, Lusiana Pusparani' ${ }^{2}$ \\ ${ }^{1)}$ Program Studi Ilmu dan Teknologi Pangan, Universitas Sebelas Maret, Surakarta \\ ${ }^{2)}$ Alumnus Program Studi Ilmu dan Teknologi Pangan, Universitas Sebelas Maret, Surakarta \\ Email: rofandi_hartanto@yahoo.com
}

Diserahkan [16 Oktober 2019]; Diterima [30 Januari 2020]; Dipublikasi [17 Februari 2020]

\begin{abstract}
The research aimed to evaluate the influence of heat source distance and smoking time of the cat fish smoked using standing type of smoked equipment, where $l \times w \times h$ is 1,000 $\mathrm{mm} \times 4,00 \mathrm{~mm} \times 2,000 \mathrm{~mm}$. It was used timber and coconut fibre as the fuel; whereas the distance from the combustion room to the hanging fish is $400 \mathrm{~mm}, 700 \mathrm{~mm}$ and 1,000 mm, respectively. The cat fish was 10 pieces per $\mathrm{kg}$, after cleaning and washing then hanging at each distance. Smoking was implemented for 2 hours, 3.5 hours and 6 hours. The research designed by completely random factorial by two factors those were distance from heat source and smoking time. Smoking was repeated two times. Then it was evaluated of the water content, ash content, fat content, protein content, carbohydrate content, $\mathrm{pH}, \mathrm{TBA}$ by twice repeating. The data was analyzed by two way ANOVA, if there is different value then continued by DMRT test at 0,05\% significant level. The research resulted that distance of heat source and smoking time were signficantly influence to moisture content, ash content, fat content, protein content, $p H$ and TBA, except the carbohydrate content which only influenced by the distance of heat source but it was not influenced by the smoking duration. The distance of $400 \mathrm{~mm}$ and duration of 6 hours resulted better smoked cat fish by moisture content of $55.61 \%--58.16 \%$, ash content of $10.56 \%--12.55 \%$, fat content of $6.88 \%--$ $9.20 \%$, protein content of $27.18 \%--29.61 \%$, carbohydrate content of $13.55 \%--18.28 \%$, pH of 5.81--6.06, TBA of $0.014 \mathrm{mgMDA} / \mathrm{kg}-0.020 \mathrm{mgMDA} / \mathrm{kg}$.
\end{abstract}

Key words: cat fish, distance of heat source, chemical characteristics, smoking time

\section{ABSTRAK}

Penelitian ini bertujuan untuk menguji pengaruh jarak dan lama pengasapan ikan lele yang diasap dengan alat pengasap tipe tegak, berukuran $\mathrm{p}$ x 1 x t adalah $1.000 \mathrm{~mm}$ x $400 \mathrm{~mm}$ x $2.000 \mathrm{~mm}$. Digunakan bahan bakar kayu dan sabut kelapa, dengan jarak dari ruang pengasapan pemanasan adalah $400 \mathrm{~mm}, 700 \mathrm{~mm}$ dan $1000 \mathrm{~mm}$. Lele segar dengan ukuran rata-rata 10 buah per kg, setelah dibersihkan diletakkan secara vertikal (digantung) pada masing-masing jarak tersebut. Dilakukan pengasapan selama 2 jam, 3,5 jam dan 6 jam. Penelitian dilakukan dengan Rancangan Acak Lengkap Faktorial dengan dua faktor, yaitu jarak dari sumber panas dan lama pengasapan. Dilakukan pengulangan pengasapan dua kali. Diuji kadar air, kadar abu, kadar lemak, kadar protein, kadar karbohidrat, nilai $\mathrm{pH}$, dan nilai TBA dengan dua kali ulangan. Data dianalisis dengan metode two way ANOVA, jika terdapat perbedaan dilakukan uji DMRT pada taraf signifikansi 0,05\%. Hasil penelitian menunjukkan jarak dari sumber panas dan lama pengasapan masing-masing berpengaruh nyata terhadap kadar air, kadar abu, kadar lemak, kadar protein, nilai pH dan nilai TBA, kecuali kadar karbohidrat yang dipengaruhi oleh jarak pengasapan tetapi tidak dipengaruhi oleh lama pengasapan. Pengasapan dengan jarak $400 \mathrm{~mm}$ dan lama pengasapan 6 jam menghasilkan lele asap yang baik dengan kandungan kadar air 55,61\%--58,16\%, kadar abu $10,56 \%--12,55 \%$, kadar lemak 6,88\%--9,20\%, kadar protein 27,18\%--29,61\%, kadar karbohidrat 13,55\%-$18,28 \%$, nilai $\mathrm{pH} 5,81-6,06$ dan nilai TBA 0,014 mgMDA/kg-0,020 mgMDA/kg.

Kata kunci: ikan lele, jarak pengasapan, karakteristik kimia, lama pengasapan

\section{PENDAHULUAN}

Ikan lele (Clarias sp.) merupakan jenis ikan yang banyak dibudidayakan di Indonesia dan menempati urutan teratas dalam jumlah hasil produksi. Perkembangan produksi ikan lele selama lima tahun antara 2010 sampai 2014 menunjukkan hasil yang sangat signifikan, yang mengalami peningkatan dari 242.811 ton menjadi 613.120 ton, dengan kenaikan rata-rata sebesar 26,43\% (Direktorat Jenderal 
Perikanan Budidaya KKP, 2015). Ikan lele merupakan jenis ikan konsumsi yang telah dikenal secara luas oleh masyarakat, karena dengan harga yang relatif murah dibandingkan jenis ikan darat lainnya, namun memiliki pemenuhan protein yang memadai. Dalam setiap 100 gram ikan lele segar terkandung 16,38 g protein, 2,82 g lemak, $0,65 \mathrm{~g}$ mineral. Selain itu, daging ikan lele juga mengandung air, vitamin $A$, vitamin $C$, vitamin $\mathrm{D}$, vitamin $\mathrm{B} 6$, vitamin $\mathrm{B} 12$, omega3, riboflavin dan thiamin (USDA, 2016). Tetapi ikan lele merupakan jenis bahan makanan yang mudah atau cepat mengalami kerusakan. Kerusakan ikan lele terutama dari pembusukan yang menyebabkan penurunan nilai gizi dan mempersingkat umur simpan.

Pengasapan merupakan salah satu cara pengolahan ikan yang berfungsi untuk mengawetkan, mempertahan nilai gizi, serta memberi aroma dan cita rasa yang khas berasal dari senyawa kimia hasil pembakaran bahan bakar (umumnya kayu). Pengasapan ikan juga berguna untuk memperpanjang umur simpan ikan lele. Seperti diketahui, ikan lele asap yang disimpan dalam suhu ruang tanpa pengemasan dapat bertahan hingga 4 sampai 8 hari (Yuliastri dkk, 2015). Proses pengasapan secara umum didefinisikan sebagai metode pengawetan ikan menggunakan kombinasi proses penggaraman (brinning), pemanasan (cooking), dan pengasapan (smoking). Selain itu, pengasapan juga dapat memberikan aroma dan cita rasa khas asap, tekstur yang bagus, warna kecoklatan serta daging yang lezat (Shabrina dkk, 2014; Wibowo, 1996).

Pada pengasapan dengan smoking cabinet, di mana alat pengasapan adalah berupa bangunan mirip rumah dengan kerangka besi atau kayu, terdiri dari bagian tungku yang terletak di bagian bawah dan tempat pengasapan di bagian atas. Dinding ditutup dengan seng dan dipasang pintu agar panas dan asap tidak terbuang. Jarak antar rak dapat diatur sehingga ikan yang disusun dengan cara digantung tidak saling bertindihan (Adawyah, 2011). Ada beberapa faktor penting dalam penentuan kualitas pengasapan ikan, diantaranya yaitu jenis bahan bakar, kadar air bahan bakar, jarak pengasapan dan lama pengasapan. Jika pengasapan tidak dilakukan dengan tepat maka akan menghasilkan senyawa karsinogenik yang tinggi dan akan menurunkan nilai gizi pada ikan. Pengasapan dilakukan menggunakan bahan bakar kayu keras (non-resinous) karena menghasilkan senyawa-senyawa asap yang nantinya akan memengaruhi kualitas ikan asap yang dihasilkan (Yuliandri dkk, 2017). Pengasapan ikan dapat menyebabkan perubahan warna, kenampakan dan konsistensi daging yang kompak dan lebih menarik, namun dapat menyebabkan penurunan maupun peningkatan komponenkomponen gizi yang ada di dalam daging ikan tersebut (Prasetyo dkk, 2015).

Dalam penelitian ini dibuat alat pengasapan yang dirancang sedemikian sehingga terdapat tiga ruang pengasapan di atas tempat pembakaran, yang memungkinkan ikan lele diletakkan (digantung) secara vertikal pada lapis bawah, tengah dan atas. Kemudian tempat pembakaran adalah berupa rak tempat kayu bakar dan sabut kelapa yang jaraknya ditentukan agar suhu pengasapan bisa diatur pada kisaran tertentu. Oleh karena itu, penelitian ini dilakukan untuk mengkaji pengaruh jarak sumber panas dan lama pengasapan ikan lele (Clarias sp.) terhadap karakteristik kimia ikan lele asap, untuk memastikan bahwa produk yang diolah masih dalam kisaran kebutuhan makanan dan baik untuk dikonsumsi.

\section{METODE PENELITIAN}

\section{Bahan}

Bahan yang digunakan dalam pembuatan ikan lele asap adalah ikan lele (Clarias sp.) berumur $\pm 2,5$ bulan dengan berat $80-85 \mathrm{~g}$, garam dapur, kayu mahoni dan sabut kelapa. Bahan untuk analisis antara lain aquades, petroleum ether, pereaksi TBA, $\mathrm{HCl} 4 \mathrm{M}$ dan $\mathrm{HCl} 0,02 \mathrm{~N}, \mathrm{H}_{2} \mathrm{SO}_{4}$ kuat, $\mathrm{K}_{2} \mathrm{SO}_{4}, \mathrm{HgO}$, batu didih, $\mathrm{H}_{3} \mathrm{BO}_{3} 4 \%$, NaOH$\mathrm{Na}$ tiosulfat, indikator MRMB.

\section{Alat}

Alat yang digunakan untuk pembuatan ikan lele asap, antara lain alat pengasap tipe tegak, keranjang plastik, pisau, baskom, 
ember plastik, talenan, timbangan analitik, termometer, kawat stainless steel diameter $1,5 \mathrm{~mm}$, timer, vacuum sealer, plastik PP. Alat yang digunakan untuk analisis antara lain botol timbang, cawan porselen, oven (Memmert), desikator (Iwaki), neraca analitik (Ohaus), penjepit, mortar, kompor listrik, tanur, kertas saring, alat ekstraksi soxhlet, kompor listrik, gelas beaker $100 \mathrm{ml}$, $\mathrm{pH}$ meter (Hanna Instruments), gelas ukur $100 \mathrm{ml}$, gelas ukur $50 \mathrm{ml}$, pipet volume $5 \mathrm{ml}$, pro pipet, tabung reaksi, spektrofotometer UV-Vis (Shimadzu), alat destilasi, labu Kjeldahl, lemari asam, buret dan statif, nampan, borang, piring saji.

Sebanyak $16 \mathrm{~kg}$ ikan lele yang telah disortasi berdasarkan ukuran dan berat dilakukan pembersihan bagian isi perut (dressing), kemudian dicuci (Sebagian ikan lele diambil untuk dilakukan analisis karakteristik kimia ikan lele segar). Ikan lele direndam dalam larutan garam 15\% selama 15 menit (Dami dkk, 2013), kemudian dicuci dengan air mengalir, selanjutnya ditiriskan. Setelah itu ikan lele digantung menggunakan kawat stainless steal pada tray pengasapan yang berjarak $40 \mathrm{~cm}, 70 \mathrm{~cm}$ dan $100 \mathrm{~cm}$ dari sumber panas. Setiap tray pengasapan berisi 60 ekor ikan lele dengan masing-masing 15 ekor ikan lele pada setiap barisnya. Pengasapan dilakukan selama 2 jam; 3,5 jam dan 6 jam.

\section{Tahapan Penelitian}

\section{Analisis Kimia}

Analisis kimia yang dilakukan yaitu: (a) kadar air metode thermogravimetri (BSN, 2006), (b) kadar abu cara kering (AOAC, 2002), (c) kadar lemak metode ekstraksi Soxhlet (AOAC, 2002), (d) kadar protein metode Kjeldahl (AOAC, 2002), (e) kadar karbohidrat by difference (AOAC, 2002), (f) nilai $\mathrm{pH}$ manual procedure (Swastawati dkk, 2013), dan (g) nilai TBA (Tarladgis, 1960).

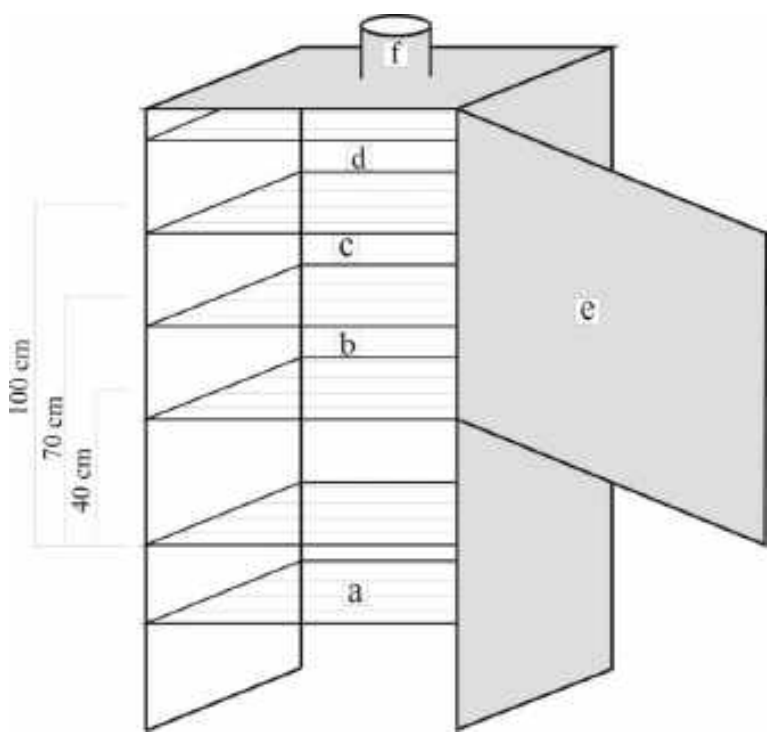

Gambar 1 Skema perspektif alat pengasap ikan lele tipe tegak

Keterangan :

a = bahan bakar

$\mathrm{b}=40 \mathrm{~cm}$ dari sumber panas

c $=70 \mathrm{~cm}$ dari sumber panas

$\mathrm{d}=100 \mathrm{~cm}$ dari sumber panas

$\mathrm{e}=$ pintu

$\mathrm{f}=$ cerobong asap

\section{Analisis Data}

Data dianalisis dengan metode two way ANOVA dengan dua faktor yaitu variasi jarak sumber panas $(40 \mathrm{~cm}, 70 \mathrm{~cm}, 100 \mathrm{~cm})$ dan lama pengasapan ( 2 jam,3,5 jam dan 6 jam). Jika menunjukkan perbedaan antar perlakuan maka dilanjutkan dengan uji beda nyata menggunakan Duncan's Multiple Range Test (DMRT) pada taraf signifikansi, $\alpha=0,05$. Besarnya pengaruh faktor perlakuan ditentukan dengan analisis model moderasi.

\section{HASIL DAN PEMBAHASAN}

Pengaruh jarak dari sumber panas terhadap karakteristik kimia ikan lele disajikan pada Tabel 1, sedangkan pengaruh lama pengasapan terhadap karakteristik kimia ikan lele disajikan pada Tabel 2, berikut ini. 
Tabel 1 Pengaruh jarak sumber panas terhadap karakteristik kimia ikan lele (Clarias sp.) asap

\begin{tabular}{cccccccc}
\hline $\begin{array}{c}\text { Jarak } \\
(\mathrm{cm})\end{array}$ & $\begin{array}{c}\text { Kadar } \\
\text { Air } \\
(\% \mathrm{wb})\end{array}$ & $\begin{array}{c}\text { Kadar } \\
\text { Abu } \\
(\% \mathrm{db})\end{array}$ & $\begin{array}{c}\text { Kadar } \\
\text { Lemak } \\
(\% \mathrm{db})\end{array}$ & $\begin{array}{c}\text { Kadar } \\
\text { Protein } \\
(\% \mathrm{wb})\end{array}$ & $\begin{array}{c}\text { Kadar } \\
\text { Karbohidrat } \\
(\% \mathrm{db})\end{array}$ & $\begin{array}{c}\text { Nilai } \\
\mathrm{pH}\end{array}$ & $\begin{array}{c}\text { Nilai TBA } \\
(\mathrm{mgMDA} / \mathrm{kg})\end{array}$ \\
\hline 40 & $58,155^{\mathrm{a}}$ & $10,556^{\mathrm{c}}$ & $6,881^{\mathrm{c}}$ & $27,180^{\mathrm{c}}$ & $18,283^{\mathrm{b}}$ & $6,058^{\mathrm{a}}$ & $0,020^{\mathrm{a}}$ \\
70 & $63,960^{\mathrm{b}}$ & $9,006^{\mathrm{b}}$ & $6,073^{\mathrm{b}}$ & $26,021^{\mathrm{b}}$ & $13,847^{\mathrm{a}}$ & $6,168^{\mathrm{b}}$ & $0,035^{\mathrm{b}}$ \\
100 & $65,315^{\mathrm{b}}$ & $7,985^{\mathrm{a}}$ & $5,266^{\mathrm{a}}$ & $25,459^{\mathrm{a}}$ & $14,010^{\mathrm{a}}$ & $6,313^{\mathrm{c}}$ & $0,048^{\mathrm{c}}$ \\
\hline
\end{tabular}

Keterangan : Angka pada kolom sama diikuti dengan huruf yang sama menunjukkan tidak berbeda nyata pada taraf signifikansi 0,05

Tabel 2 Pengaruh lama pengasapan terhadap karakteristik kimia ikan lele (Clarias sp.) asap

\begin{tabular}{cccccccc}
\hline $\begin{array}{c}\text { Lama } \\
(\text { jam })\end{array}$ & $\begin{array}{c}\text { Kadar } \\
\text { Air } \\
(\% \text { wb })\end{array}$ & $\begin{array}{c}\text { Kadar } \\
\text { Abu } \\
(\% \text { db })\end{array}$ & $\begin{array}{c}\text { Kadar } \\
\text { Lemak } \\
(\%)\end{array}$ & $\begin{array}{c}\text { Kadar } \\
\text { Protein } \\
(\% w b)\end{array}$ & $\begin{array}{c}\text { Kadar } \\
\text { Karbohidrat } \\
(\% \text { db })\end{array}$ & $\begin{array}{c}\text { Nilai } \\
\text { pH }\end{array}$ & $\begin{array}{c}\text { Nilai TBA } \\
(\text { mgMDA/kg })\end{array}$ \\
\hline 2 & $68,764^{\mathrm{c}}$ & $5,926^{\mathrm{a}}$ & $3,397^{\mathrm{a}}$ & $23,297^{\mathrm{a}}$ & $15,902^{\mathrm{a}}$ & $6,565^{\mathrm{c}}$ & $0,060^{\mathrm{c}}$ \\
3,5 & $63,056^{\mathrm{b}}$ & $9,067^{\mathrm{b}}$ & $5,629^{\mathrm{b}}$ & $25,750^{\mathrm{b}}$ & $16,685^{\mathrm{a}}$ & $6,163^{\mathrm{b}}$ & $0,030^{\mathrm{b}}$ \\
6 & $55,609^{\mathrm{a}}$ & $12,554^{\mathrm{c}}$ & $9,195^{\mathrm{c}}$ & $29,614^{\mathrm{c}}$ & $13,553^{\mathrm{a}}$ & $5,811^{\mathrm{a}}$ & $0,014^{\mathrm{a}}$ \\
\hline
\end{tabular}

Keterangan : Angka pada kolom sama diikuti dengan huruf yang sama menunjukkan tidak berbeda nyata pada taraf signifikansi 0,05

\section{Kadar air}

Kadar air ikan lele asap yang sesuai dengan SNI $(\leq 60 \%)$ yaitu perlakuan jarak sumber panas $40 \mathrm{~cm}$ sebesar $58,155 \%$. Sedangkan pada jarak $70 \mathrm{~cm}$ dan $100 \mathrm{~cm}$ dari sumber panas memiliki kadar air yang melebihi batas standar SNI. Hal ini disebabkan karena semakin jauh jarak sumber panas penetrasi panas dari asap akan berlangsung lambat, sehingga tingkat penguapan kadar air menjadi lambat dan nilai kadar airnya akan tinggi (Sumartini dkk., 2014). Pada perlakuan lama pengasapan, kadar air ikan lele asap yang sesuai dengan SNI yaitu pada perlakuan lama pengasapan 6 jam sebesar $55,609 \%$. Sedangkan pada lama pengasapan 3,5 jam dan 2 jam kadar airnya masih melebihi batas SNI. Diduga singkatnya waktu pengasapan menjadi penyebab masih tingginya kadar air ikan lele asap. Seperti juga dinyatakan singkatnya waktu pengasapan menyebabkan proses penguapan air dari tubuh ikan tidak stabil dan menyebabkan kandungan air masih relatif tinggi (Leki dan Mamiek, 2017). Tetapi pengasapan yang langsung menggunakan suhu tinggi dapat menyebabkan kandungan air pada permukaan tubuh ikan akan cepat menguap dan permukaan ikan cepat matang sehingga kandungan air yang ada di dalam daging ikan tidak dapat keluar dan daging ikan menjadi kurang matang (Suprayitno, 2017). Meskipun perlakuan penggaraman sebesar $15 \%$ diduga berkontribusi terhadap penurunan kadar air ikan, namun lama pengasapan lebih menentukan kadar air akhir ikan lele asap.

\section{Kadar abu}

Tabel 1 menunjukkan bahwa semakin dekat jarak sumber panas, kadar abu yang dihasilkan semakin meningkat dengan nilai kadar abu tertinggi yaitu perlakuan jarak sumber panas $40 \mathrm{~cm}$ sebesar 10,556\%. Semakin dekat dengan sumber panas suhu akan meningkat dan semakin banyak residu yang ditinggalkan dalam bahan karena menurunnya kadar air (Yuniarti dkk, 2013). Sedangkan pada Tabel 2 menunjukkan bahwa semakin lama proses pengasapan, kadar abu yang dihasilkan semakin meningkat dengan nilai kadar abu tertinggi yaitu perlakuan lama pengasapan 6 jam sebesar 12,554\%. Persentase kadar abu berkolerasi positif terhadap lamanya pengasapan.

Kandungan mineral-mineral ikan lele segar juga mempengaruhi kadar abu ikan lele asap, selain itu proses penggaraman juga dapat mempengaruhi kadar abu ikan lele asap karena mengandung mineral tertentu 
(Sumaryanto dkk, 2017). Edinov dkk, (2013) menjelaskan bahwa pemberian garam menyebabkan jumlah mineral natrium di dalam daging ikan meningkat sehingga kadar abunya juga meningkat.

Perbedaan jarak sumber panas, lama pengasapan, dan interaksi antara jarak sumber panas dengan lama pengasapan memberikan pengaruh nyata terhadap kadar abu ikan lele asap. Jarak sumber panas memberikan pengaruh sebesar $12,6 \%$, lama pengasapan memberikan pengaruh sebesar $82,7 \%$ dan interaksi antara jarak sumber panas dengan lama pengasapan memberikan pengaruh sebesar 2,4\% terhadap kadar abu ikan lele asap.

\section{Kadar lemak}

Dari Tabel 1 dapat dilihat bahwa semakin dekat jarak sumber panas, kadar lemak yang dihasilkan semakin meningkat. Kadar lemak ikan lele asap yang dihasilkan dari semua perlakuan sesuai dengan SNI $(\leq 20 \%)$ dengan nilai kadar lemak tertinggi yaitu perlakuan jarak sumber panas $40 \mathrm{~cm}$ sebesar $6,881 \%$. Semakin dekat jarak sumber panas maka suhu semakin tinggi dan akan menyebabkan kadar air semakin berkurang sehingga total solid dalam sampel meningkat, kadar lemak akan meningkat seiring dengan meningkatnya total solid (Novia dkk, 2012). Dari Tabel 2 dapat dilihat bahwa semakin lama proses pengasapan, kadar lemak yang dihasilkan semakin meningkat. Kadar lemak ikan lele asap yang dihasilkan dari semua perlakuan sesuai dengan SNI, dengan nilai kadar lemak tertinggi yaitu perlakuan lama pengasapan 6 jam sebesar 9,195\%. Peningkatan kadar lemak selama proses pengasapan disebabkan oleh lamanya ikan lele kontak dengan asap panas. Shabrina dkk (2014) menyatakan semakin lama proses pengasapan maka asap yang menempel pada daging ikan lele akan semakin pekat, sehingga kadar fenol pada ikan lele semakin tinggi. Girrad (1992) dan Novia dkk (2012) menyebutkan bahwa senyawa fenol dari asap dalam konsentrasi kecil dapat memperlihatkan efektivitasnya sebagai penghambat reaksi oksidasi lemak. Siringol merupakan senyawa fenol yang paling berperan sebagai antioksidan. Siringol dapat mencegah proses oksidasi senyawa lemak sehingga proses pemecahan senyawa tersebut terhambat. Fenol dapat mencegah oksidasi lemak karena kemampuannya untuk menyumbangkan hidrogen ke radikal peroksi sehingga menghentikan reaksi berantai. Adanya antioksidan ini maka akan membentuk radikal antioksidan dan berubah menjadi senyawa yang lebih stabil (Hui, 2012).

Interaksi antara jarak sumber panas dengan lama pengasapan memberikan pengaruh nyata terhadap kadar lemak ikan lele asap. Jarak sumber panas memberikan pengaruh sebesar 7\%, lama pengasapan memberikan pengaruh sebesar 91,3\% dan interaksi antara jarak sumber panas dengan lama pengasapan memberikan pengaruh sebesar $1 \%$ terhadap kadar lemak ikan lele asap.

\section{Kadar protein}

Tabel 1 menunjukkan bahwa semakin dekat jarak sumber panas, kadar protein yang dihasilkan semakin meningkat dengan nilai kadar protein tertinggi yaitu perlakuan jarak sumber panas $40 \mathrm{~cm}$ sebesar $27,180 \%$. Batas kerusakan protein adalah suhu denaturasinya, sehingga pengolahan menggunakan suhu tinggi dapat menyebabkan protein ikan lele terdenaturasi. Denaturasi protein ikan yang dimulai pada suhu $40^{\circ} \mathrm{C}$, dan optimum pada suhu $65-68^{\circ} \mathrm{C}$. Sedangkan apabila dipanaskan pada suhu $50^{\circ} \mathrm{C}$ atau lebih, protein yang terdenaturasi akan mengalami koagulasi (Sulistijowati dkk, 2011). Proses pengasapan dapat meningkatkan kandungan protein yang tidak dapat larut yaitu stroma protein serta dapat mengurangi jumlah protein yang larut dalam air yaitu miofibril dan sarkoplasma (Swastawati dkk, 2013; Pundoko dkk, 2014).

Tabel 2 menunjukkan bahwa semakin lama proses pengasapan, kadar protein yang dihasilkan semakin meningkat dengan nilai kadar protein tertinggi yaitu perlakuan lama pengasapan 6 jam sebesar 29,614\%. Peningkatan kadar protein disebabkan peningkatan kandungan Nitrogen sebagai komponen asam amino sejalan dengan hilangnya elemen Hidrogen karena pemanasan. Kandungan protein dapat berubah akibat adanya senyawa asap. 
Senyawa formaldehid akan menyebabkan kelarutan protein menjadi rendah (Harris dan Karmas, 1989). Menurut Prasetyo dkk (2015) pengasapan dapat mengurangi kandungan lisin. Hilangnya lisin biasanya terjadi pada tahap awal pengasapan dengan api yang tinggi. Biasanya pada tahap awal pengasapan digunakan suhu yang rendah untuk menghindari kehilangan lisin.

Perbedaan jarak sumber panas, lama pengasapan memberikan pengaruh nyata terhadap kadar protein ikan lele asap, sedangkan interaksi antara jarak sumber panas dengan lama pengasapan tidak memberikan pengaruh nyata terhadap kadar protein ikan lele asap.

\section{Kadar karbohidrat}

Perbedaan jarak sumber panas memberikan hasil nilai kadar karbohidrat yang fluktuatif. Nilai kadar karbohidrat tertinggi yaitu perlakuan jarak sumber panas $40 \mathrm{~cm}$ sebesar 18,283\%. Semakin dekat dengan sumber panas maka suhu yang dihasilkan akan lebih tinggi. Menurut Fennema (1996) adanya suhu panas dan asam dapat menyebabkan karbohidrat kompleks mengalami hidrolisis menjadi senyawa-senyawa karbohidrat yang lebih sederhana. Demikian juga perbedaan lama pengasapan menghasilkan nilai kadar karbohidrat yang fluktuatif. Nilai kadar karbohidrat tertinggi yaitu perlakuan lama pengasapan 3,5 jam sebesar 16,685\%. Seharusnya semakin lama pengasapan maka kadar karbohidrat semakin meningkat karena jumlah bahan bakar yaitu kayu dan sabut kelapa yang terbakar semakin banyak. Budiarti dkk (2016) menyatakan pengasapan dengan bahan bakar kayu keras dan sabut kelapa dapat menambah kadar karbohidrat dari ikan lele asap. Hal ini dikarenakan kayu keras dansabut kelapa mengandung selulosa dan lignin. Akintola dkk (2013) menambahkan bahwa selama proses pemanasan, serat kasar yang membentuk dinding sel berkurang tetapi komponen karbohidrat relatif meningkat dari sampel segar.

Perbedaan jarak sumber panas dan interaksi antara jarak sumber panas dengan lama pengasapan memberikan pengaruh nyata terhadap kadar karbohidrat ikan lele asap, sedangkan perbedaan lama pengasapan tidak memberikan pengaruh nyata terhadap kadar karbohidrat ikan lele asap. Jarak sumber panas memberikan pengaruh sebesar $8 \%$, lama pengasapan memberikan pengaruh sebesar $3,1 \%$ dan interaksi antara jarak sumber panas dengan lama pengasapan memberikan pengaruh sebesar $34,9 \%$ terhadap kadar karbohidrat ikan lele asap.

\section{Nilai pH}

Semakin dekat jarak sumber panas, nilai $\mathrm{pH}$ yang dihasilkan semakin menurun. Semakin dekat dengan sumber panas maka penetrasi asap yang menempel pada tubuh ikan akan lebih banyak dibandingkan dengan pengasapan yang jauh dengan sumber panas. Menurunnya $\mathrm{pH}$ setelah pengasapan dapat dikaitkan dengan komponen asam dalam asap, seperti asam asetet, asetat butirat (Turan dkk, 2008). Sumartini dkk. (2014) menjelaskan bahwa pengasapan dengan jarak yang dekat dengan sumber panas menyebabkan nilai total asam meningkat, hal ini yang mengakibatkan nilai $\mathrm{pH}$ menjadi turun.

Semakin lama proses pengasapan, nilai $\mathrm{pH}$ yang dihasilkan semakin menurun. Pengasapan yang berlangsung lebih lama, unsur asap yang terserap dan melekat pada produk lebih banyak, demikian juga senyawa asam yang terserap juga meningkat (Katiandagho dkk, 2017). Semakin tinggi kadar asam pada suatu produk maka semakin rendah nilai $\mathrm{pH}$ ikan asap maka semakin panjang umur simpan dari produk ikan asap tersebut (Arif dkk, 2015).

Perbedaan jarak sumber panas, lama pengasapan, dan interaksi antara jarak sumber panas dengan lama pengasapan memberikan pengaruh nyata terhadap nilai $\mathrm{pH}$ ikan lele asap. Jarak sumber panas memberikan pengaruh sebesar 9,5\%, lama pengasapan memberikan pengaruh sebesar $80,8 \%$ dan interaksi antara jarak sumber panas dengan lama pengasapan memberikan pengaruh sebesar $0,1 \%$ terhadap kadar air ikan lele asap. 


\section{Nilai TBA (Thiobarbituric-acid)}

Nilai asam thiobarbiturat (TBA) digunakan untuk menilai tingkat kerusakan ikan terutama pada ikan berlemak. Ketengikan oksidatif pada bahan pangan berhubungan dengan besarnya nilai TBA (Adeyeye dkk, 2016). Analisis nilai TBA bertujuan untuk mengetahui jumlah malonaldehid yang terbentuk setelah pengasapan ikan lele.

Batas maksimum bilangan asam thiobarbiturat yang masih dapat diterima yaitu sebesar 2,0 $\mathrm{mg}$ malonaldehid per $\mathrm{kg}$ daging. Lebih dari batas tersebut maka produk dianggap tengik dan tidak layak untuk dikonsumsi (Campo dkk, 2006). Menurut Kuo dan Chu (2003), nilai bilangan asam thiobarbiturat yang berkisar antara 0,5$2,0 \mathrm{mg}$ malonaldehid $/ \mathrm{kg}$ telah mengindikasikan adanya flavor tengik.

Semakin dekat jarak sumber panas, nilai TBA yang dihasilkan semakin menurun dengan terendah jarak sumber panas $40 \mathrm{~cm}$ sebesar 0,020 mgMDA/kg. Berdasarkan hasil penelitian ini, semua perlakuan memberi nilai TBA yang masih berada dalam batas aman. Semakin dekat dengan sumber panas maka senyawa asap yaitu fenol yang menempel dan terserap dalam daging ikan lele akan semakin banyak. Senyawa fenol hasil dari proses pengasapan berfungsi sebagai antioksidan yang dapat menekan tingkat oksidasi lemak, sehingga nilai TBA yang dihasilkan rendah. Semakin lama proses pengasapan, nilai TBA yang dihasilkan semakin menurun, lama pengasapan 6 jam sebesar 0,014 mgMDA/kg. Semakin lama waktu pengasapan maka senyawa-senyawa dari asap yang menempel pada tubuh ikan akan semakin banyak dan dapat menghambat oksidasi lemak. Apituley dan Purnama (2013) menjelaskan bahwa kerusakan oksidatif lemak ikan dapat ditekan dengan proses pengasapan. Sifat antioksidatif dari senyawa asap disebabkan karena kandungan senyawa-senyawa fenolik seperti siringol (2,6-dimetoksifenol) dan guaiakol (2-metoksi fenol).

Perbedaan jarak sumber panas, lama pengasapan, dan interaksi antara jarak sumber panas dengan lama pengasapan memberikan pengaruh nyata terhadap nilai
TBA ikan lele asap. Jarak sumber panas memberikan pengaruh sebesar $23,1 \%$, lama pengasapan memberikan pengaruh sebesar $61,6 \%$ dan interaksi antara jarak sumber panas dengan lama pengasapan memberikan pengaruh sebesar 3,4\% terhadap nilai TBA ikan lele asap.

\section{KESIMPULAN}

Berdasarkan penelitian yang telah dilakukan, dapat diambil kesilmpulan bahwa perlakuan jarak sumber panas $40 \mathrm{~cm}, 70 \mathrm{~cm}$, $100 \mathrm{~cm}$ berpengaruh nyata terhadap kadar air, kadar abu, kadar lemak, kadar protein, kadar karbohidrat, nilai $\mathrm{pH}$ dan nilai TBA ikan lele asap. Perlakuan lama pengasapan 2 jam, 3,5 jam, 6 jam berpengaruh nyata terhadap kadar air, kadar abu, kadar lemak, kadar protein, nilai $\mathrm{pH}$ dan nilai TBA ikan lele asap, tetapi tidak berpengaruh nyata terhadap kadar karbohidrat ikan lele asap.

Perlakuan jarak sumber panas $40 \mathrm{~cm}$ dan lama pengasapan 6 jam merupakan kondisi yang baik untuk pengasapan ikan lele dengan hasil kandungan kadar air 55,61\%-$58,16 \%$, kadar abu 10,56\%--12,55\%, kadar lemak 6,88\%--9,20\%, kadar protein $27,18 \%$ $-29,61 \%$, kadar karbohidrat 13,55\%-$18,28 \%$, nilai $\mathrm{pH} 5,81-6,06$ dan nilai TBA $0,014 \mathrm{mgMDA} / \mathrm{kg}-0,020 \mathrm{mgMDA} / \mathrm{kg}$.

\section{DAFTAR PUSTAKA}

Adeyeye, S. A. O., Alusola B. O., Olusegun A. O., A. M. Omemu., O. E. Adeniran., H. A. Oyedele., Adetola O dan Saheed A. O. 2016. Effect of Smoking Methods on Quality and Safety of Traditional Smoked Fish from Lagos State, Nigeria.Journal of Culinary Science \& Technology 1-19.

Akintola, S. L., Ayodele B., Abubakar B., Aluwafemi D. O dan Beatrice O. B. 2013. Effects of Hot Smoking and Sun Drying Processes on Nutritional Composition of Giant Tiger Shrimp (Penaeus monodon, Fabricius, 1798).Polish Journal of Food and Nutrition Sciences 63(4): 227-237. 
Apituley, D. A. $\mathrm{N}$ dan Purnama D. 2013.Daya Hambat Asap Cair Kulit Batang Sagu terhadap Kerusakan Oksidatif Lemak Ikan Tuna (Thunnus sp) Asap.Jurnal Agritech 33(2): 162167.

Arif, A., Sukirno M dan Tjipto L. 2015. Pengaruh Perbedaan Bahan Baku Asap terhadap Mutu Ikan Patin (Pangasius hypophthalmus) Asap.Fakultas Perikanan dan Ilmu Kelautan, Universitas Riau.

Association of Official Analytical Chemist. 2002. Official Methods of Analysis Association of Official Analytical Chemist. Benjamin Franklin Station, Washington.

BSN. 2006. Cara Uji Kimia- Bagian 2: Penentuan Kadar Air pada Produk Perikanan SNI-01-2354.2-2006. Badan Standardisasi Nasional. Jakarta.

BSN.2013. Ikan Asap dengan Pengasapan Panas SNI 2725:2013.Badan Standardisasi Nasional. Jakarta.

Budiarti, I. D. S., Fronthea S dan Laras R. 2016. Pengaruh Perbedaan Lama Perendaman dalam Asap Cair terhadap Perubahan Komposisi Asam Lemak dan Kolesterol Belut (Monopterus albus) Asap.Jurnal Pengolahan \& Bioteknologi Hasil Perikanan 5(1): 125135.

Campo, M. M., G. R. Nute., S. I. Hughes., M. Enser., J. D. Wood dan R. I. Richardson. 2006. Flavour Perception of Oxidation in Beef. Journal Meat Science 72: 303-311.

Direktorat Jenderal Perikanan Budidaya Kementerian Kelautan dan Perikanan. 2015. Laporan Kinerja Direktorat Jenderal Perikanan Budidaya Tahun 2014. Jakarta.

Edinov, S., Yefrida., Indrawati dan Refilda. 2013. Pemanfaatan Asap Cair Tempurung Kelapa pada Pembuatan Ikan Kering dan Penentuan Kadar Air, Abu serta Proteinnya. Jurnal Kimia Unand 2(2): 29-35.
Harris, R. S dan E. Karmas. 1989. Evaluasi Gizi Pada Pengolahan Bahan Pangan Penerbit ITB. Bandung.

Hui, Y. H. 2012. Handbook of Meat Processing.CRC Press. New York.

Katiandagho, Y., Siegfried B dan Albert R. R. 2017. Pengaruh Konsentrasi Asap Cair dan Lama Perendaman terhadap Mutu Organoleptik Ikan Kayu (Katsuobushi).Jurnal Media Teknologi Hasil Perikanan 5(1): 95-101.

Kuo, C. C dan C. Y. Chu. 2003. Quality Characteristics of Chinese Sausages Made from PSE Pork. Journal Meat Science 64: 441-449.

Leki, A dan Mamiek M. 2017.Karakteristik Mutu Se'i Tuna yang Diproses Menggunakan Metode Liquid Smoking, Smoking Cabinet dan Tungku Tradisional.Prosiding Sentrinov 3.

Novia, D., I. Juliyarsi dan G. Faudi. 2012. Kadar Protein, Kadar Lemak dan Organoleptik Telur Asin Asap Berbahan Bakar Sabut Kelapa. Jurnal Peternakan 9(1): 35-45

Prasetyo, D. Y. B., Yudhomenggolo S. D dan Fronthea S. 2015. Efek Perbedaan Suhu Dan Lama Pengasapan Terhadap Kualitas Ikan Bandeng (Chanos Chanos Forsk) Cabut Duri Asap. Jurnal Aplikasi Teknologi Pangan 4(3).

Pundoko, S. S., Hens O dan Agnes T. A. 2014. Perubahan Komposisi Zat Gizi Ikan Cakalang Katsuwonus pelamis.L Selama Proses Pengolahan Ikan Kayu.Jurnal Media Teknologi Hasil Perikanan 2(1): 9-14.

Shabrina, N. A., Putut H. R dan Apri D. A. 2014. Pengaruh Jarak, Suhu, Lama Pengasapan terhadap Kemunduran Mutu Ikan Bandeng (Chanos chanos Forks) Asap Selama Penyimpanan Suhu Ruang.Jurnal Pengolahan dan Bioteknologi Hasil Perikanan 3(3): 6874.

Sulistijowati, R., Otong S. D., Jetty N., Eddy A dan Zalinar U. 2011. Mekanisme 
Pengasapan Ikan. Unpad Press.

Bandung.

Sumartini., Forenthea S dan Tri W. A. 2014. Analisis Asam Lemak Omega 3,6,9 dan Kadar Fenol Ikan Bandeng (Chanos chanos Forsk) Asap dengan Kombinasi Jarak Tungku dan Lama Pengasapan. Jurnal Pengolahan dan Bioteknologi Hasil Perikanan 3(1): 157-166.

Sumaryanto, H., Rusky I. P., Joko S., Tjahja M., Tatty Y dan Luthfi A. 2017. Karakteristik Kimia Ikan Salai. Prosiding Seminar Nasional Inovasi Teknologi Pengolahan Produk dan Bioteknologi Kelautan dan Perikanan III: $157-162$

Suprayitno, E. 2017.Dasar Pengawetan. UB Press. Malang.

Swastawati, F., Y. S. Darmanto., L. Sya'rani., Rahayu K and K. D. Anthony T. 2014. Quality Characteristics of Smoked Skipjack (Katsuwonuspelamis) Using Different Liquid Smoke. International Journal of Bioscince, Biochemistry and Bioinformatics 4(2): 94-99.

Turan, H., Gulsah S., M. Yesim C., Metin Y dan Yalcin K. 2008. The Effects of Hot Smoking and Shelf Life of Mediterranean Mussel (Mytilus galloprovincialia L. 1819) Under Chilled Storage.Journal of Food Processing and Preservation 32: 912922. 